\title{
Examination of Narcissistic Behaviors of Physical Education Teachers and Their Relationship with Job Satisfaction
}

\author{
Orhan GÖK ${ }^{1}$, Kürşat HAZAR ${ }^{1} \&$ Ahmet F. KOÇ ${ }^{1}$ \\ ${ }^{1}$ High School of Physical Education and Sports, Osmaniye Korkut Ata University, Osmaniye \\ Correspondence: Kürşat Hazar, High School of Physical Education and Sports, Osmaniye Korkut Ata University, \\ Osmaniye. Email: kursathazar@hotmail.com
}

Received: May 30, 2021

Accepted: June 30, $2021 \quad$ Online Published: July 6, 2021

doi:10.5539/jel.v10n4p192

URL: https://doi.org/10.5539/jel.v10n4p192

\begin{abstract}
This study was conducted to reveal the relationships between physical education teachers' narcissistic behaviors and job satisfaction. This research was designed in a correlational survey model, 195 physical education teachers, 41 females, and 154 males were selected by the simple random sampling among the physical education teachers working in Kurıkkale and Osmaniye provinces, participated in the study voluntarily. In the study, "Personal Information Form" was used to determine the demographic characteristics of the participants, "Narcissistic Personality Inventory-13 (NPI-13)" was used to determine the demographic characteristics of the participants, and the "Job Satisfaction Scale" was used to determine the level of job satisfaction. In the analysis of the data, it was decided whether the descriptive statistics (standard deviation, frequency, arithmetic mean) met the conditions of the parametric tests or not by looking at the Skewness and Kurtosis values and the Levene test results. Since the skewness and kurtosis values obtained in the study were between $(-1)$ and $(+1)$, the applicability of the parametric tests was decided and T-test, One-Way analysis of variance (ANOVA) Pearson correlation coefficient, and simple linear regression analysis were used. As a result of the study, it was determined that the narcissistic behaviors of physical education teachers were moderate and their job satisfaction was high. It was found that there is no significant relationship between narcissistic behaviors and job satisfaction $p>0.05$. It was determined that the narcissistic behaviors showed a significant difference between the variables of educational status, age, and status of taking part in sportive activities $\mathrm{p}<0.05$. The results obtained from this research; showed that physical education teachers' narcissistic behavior levels did not differ significantly according to gender and branch type, but it was concluded that there was a significant difference according to the variables of educational status, age, the status of taking part in sportive activities and the levels of narcissistic behavior did not affect the job satisfaction of physical education teachers in their professional lives.
\end{abstract}

Keywords: physical education teacher, job satisfaction, narcissism

\section{Introduction}

The story of Narcissus, who has been the symbol of selfishness, boasting, and arrogance in art and literature for centuries, has influenced the formation of the concept of narcissism. As described in mythologies, Narcissus sees himself with the reflection of the water while walking by the lake, falls in love, and dies by drowning in the water while trying to cling to this reflection. Narcissus' high interest in him attracted the attention of scientists at the end of the 19th century and has been the subject of research.

Studies indicate that narcissistic behavior is a personality trait that is more important than other people and is characterized by a sense of entitlement. It means that individuals feel a connection to their own body, spiritual self or character, arrogance, and lack of empathy (Reijntjes et al., 2016). Narcissists are people who appreciate themselves physically and spiritually, regard themselves as superior, expect appreciation, attention, and approval, and believe that they will receive special attention in every environment they are in (Timuroğlu \& İşcan, 2008). Foster and Campbell (2007), on the other hand, stated that narcissism is a personality disorder that has the characteristics of belittling individuals, expecting admiration, lacking understanding of empathy, and wanting to be accepted. Narcissism is not something individuals have or do not have; rather, it is a personality disorder in which individuals change from "non-narcissist" to "narcissistic" without a significant transition.

It can be defined as a personality trait characterized by a sense of self-importance and a desire to receive special treatment (Grapsas et al., 2020). According to Reijntjes (2016), it is a personality trait that includes beliefs of 
personal superiority and the desire to receive special treatment. Narcissists tend to influence others. Often, they enhance their appearance to attract others' attention, brag about themselves, and showcase their talents in front of others. However, narcissism can occur not only in behavior but also in thoughts and feelings (Timuroğlu \& İşcan, 2008).

In the literature, it is characterized by a variety of characteristics ranging from aggression, assertiveness, beliefs of personal greatness, feelings of superiority, arrogance, and combativeness (Grapsas et al., 2020). At the same time, narcissists are often aggressive towards others. In such situations, they are often perceived as confrontational, humiliating, condescending, and frightening (Reijntjes et al., 2016). According to Godkin and Allcorn (2011), conflict or tensions between employees in businesses can be a strong cause of employees' dissatisfaction with their jobs, and this situation can be exacerbated by the fact that one of the employees among them is a narcissistic individual. It is stated that success in businesses is closely related to job satisfaction and the performance of employees. While the relationship between narcissism and job satisfaction was associated with productivity and quality, it was stated that the employee's absenteeism and leaving the job were the result of job dissatisfaction. According to Mahmood et al. (2019), job satisfaction is defined as "the series of positive or negative emotions and feelings employees feel about their job". Businesses have focused on people to ensure success. Businesses that understand the importance of human resources focus not on product, technology, or economic concerns, but on how people can work together most efficiently. It has become important for businesses to ensure job satisfaction by revealing the potential talents of employees (Timuroğlu \& İşcan, 2008). Although narcissism is one of the oldest phenomena in the history of science, interest in narcissism has increased in recent years, thanks to researches aimed at understanding its relationships with various organizational variables (Ames et al., 2006; Brown et al., 2009). Yelboğa (2007) stated that individual characteristics have an effect on job satisfaction and stated that a positive behavior that emerges as a result of employees finding what they expect from their job is job satisfaction. Employees' genetic tendency, family factor, the education they have received, value judgments, work-life experience, social structure, and environment play an important role in job satisfaction. These personal factors have a positive or negative effect on the attitude of the staff towards the organization in meeting the expectations. It is assumed in the relevant literature that there is a relationship between the personality traits of employees and their job satisfaction levels (Yıldırım, 2014).

Studies aiming to examine how narcissistic personality disorder, which we encounter as a social problem in workplaces, bilateral relations, and family life, affects businesses and the job satisfaction of employees has increased in recent years. Increasing mobbing in business life, narcissistic behavior by employers and frequent problems among colleagues raise the need for work-oriented awareness studies on personality problems.

With the understanding of the concept of narcissism, businesses and institutions aimed to use the beneficial aspects of narcissism by reducing its harmful sides. It has been observed that narcissists may have negative sides as well as positive sides that they contribute to businesses. It has been stated that narcissistic individuals focus too much to achieve success by compromising themselves. Although these individuals are brought to the position of leaders among their colleagues with their superior success and effort, it has been observed that issues such as organizational commitment also make positive contributions to other employees. Studies conducted on adult individuals show that individuals with relatively high levels of narcissism tend to take leadership roles in business life. For bosses and colleagues, these individuals may be seen as suitable for such roles because they match people's expectations of how a leader should be. Many people believe that a leader should be charismatic, confident, attractive. Individuals with relatively high levels of narcissism are often viewed as attractive, charismatic, and confident, as they tend to be confident, embrace bold visions, and be confident in their abilities. As a result, narcissistic individuals are likely to emerge as leaders (Grijalva et al., 2015).

When relatively narcissistic personalities take on leadership roles, they may not be of benefit to their business. Although these individuals often see themselves as a useful and effective leader personality, they can be oppressive to their environment and ignore the contributions from their environment. In collaborative activities, they may tend to damage the performance of employees due to blocking the exchange of information between employees (Brummelman et al., 2021).

According to Lubit (2002), narcissists are dominant, selfish, and controlling in the organizations they are responsible for, they also oppose criticism, comment on their weaknesses, and blame their employees. They are too shy about accepting challenges from subordinates, can be very detrimental in team environments, and are not good for an organization's overall health. Narcissistic bosses feel threatened and try to minimize the people working under them, so even the best employees in an organization may quit their jobs because of this, which points to another negative consequence of narcissism. In the light of all this information in the literature, it has been stated that the personality factor of individuals has a close relationship with the job satisfaction or 
dissatisfaction they obtain from their job (İbrahim et al., 2012). In this context, the study was conducted to determine the narcissistic behavior and job satisfaction levels of physical education teachers and to reveal the relationships between physical education teachers' narcissistic behavior and job satisfaction. Accordingly, the following questions were sought within the scope of the research:

- What are the narcissistic behaviors and job satisfaction levels of Physical Education teachers?

- Identifying statistical differences between narcissistic behaviors in physical education teachers and job satisfaction

- The examination of some variables (age, gender, status of takin part in sportive activities and branch type) on narcissistic behaviors and job satisfaction

\section{Methodology}

In the method section, explanations about the model to be used within the scope of the research, research group, data collection and analysis processes are given.

\subsection{Research Model}

In this study, the job satisfaction and narcissism levels of physical education teachers were compared in terms of gender, educational status, age, branch type, and sports activity. In line with the purpose of the research, this research is descriptive research using the correlational survey model, one of the quantitative research methods. This method is used to grasp and explain the relationship between various variables without any attempt to change the current situation (Büyüköztürk et al., 2009). In this framework, a research model that aims to determine the existence of co-change between two or more variables has been created.

\subsection{Research Group}

Physical education teachers constitute the universe of this research. The population of the research is physical education teachers working in Kirıkkale and Osmaniye provinces. The research group consists of 195 participants (41 Female, $21 \%$, age $\bar{X}=39.09 ; 154$ Male, 79\%, age $\bar{X}=40.45$ ) among the physical education teachers who were selected by thesimple random sampling among the non-random sampling methods and actively work in the provinces of Kirkkale and Osmaniye ( 2 different cities are located in different geographical regions in Turkey). The average age of the participants was determined to be 40.16 .

\subsection{Data Collection Method}

Due to the difficulties in reaching individuals face to face due to the global epidemic, the data was converted into an online questionnaire. The "Narcissistic Personality Inventory-13 (NPI-13)" scale was used to determine the narcissism levels of the physical education teachers who voluntarily participated in the study, and the "Job Satisfaction Scale" was used to determine the job satisfaction levels. The "Personal Information Form" prepared by the researchers was used to collect information about demographic characteristics (gender, educational status, age, income, tenure, branch type, sport status, and national sports background).

Narcissistic Personality Inventory-13 (NPI-13) Scale: It was developed by Gentile et al. (2013) and its validity and reliability study in our country was carried out by Doğan and Çolak (2020). There are a total of 13 items on the scale. Sample items; $1-\mathrm{I}$ like to have authority over other people, 2-I am a born leader, 3-I like to look at me in the mirror. The scale consists of 3 sub-dimensions. These are the sub-dimensions of "Authority", "Conspicuousness", and "Exploitation". Participants stated the frequency of exhibiting the behavior specified by each item on a Likert-type 5-rating scale. The evaluations were made by giving (5) points to the strongly agree option, and (1) points to the strongly disagree option. The Cronbach alpha internal consistency coefficients calculated based on the item analysis of the scale were calculated as .75 for the authority factor, .71 for the conspicuousness factor, and .68 for the exploitation factor. The Cronbach alpha internal consistency coefficient calculated based on the item analysis for the full scale was calculated as .83 .

Job Satisfaction Scale: A 5-item short form was created by Judge et al. (1998), which was developed by Brayfield and Rothe (1951). The scale was adapted to Turkish by Keser and Bilir (2019). The job satisfaction scale has been prepared to reveal the job satisfaction level. There are a total of 5 items on the scale. Two of these items ( 3 rd and 5th) were prepared as the reverse item.

Participants stated the level of satisfaction indicated by each item on a Likert-type 5-point scale. The evaluations were made by giving (5) points to the strongly agree option and (1) to the strongly disagree option. The Cronbach alpha internal consistency coefficient calculated based on the item analysis of the scale was calculated as .78. 


\subsection{Data Analysis}

Within the scope of the research, the analyzes applied for the data obtained from the "Personal Information Form", "Narcissistic Personality Inventory-13 (NPI-13) Scale" and "Job Satisfaction Scale" were performed through the SPSS 26.0 program. Before analyzing the data, the forms obtained were reviewed and 3 questionnaires that were not filled in accordance with the instructions or left blank were removed from the research. 195 questionnaires, which were filled voluntarily and in accordance with their purpose, were evaluated. As a statistical method during the evaluation of the obtained data; Descriptive statistics (standard deviation, frequency, arithmetic mean), t-test, one-way analysis of variance (ANOVA), Tukey HSD multiple comparison test from Post Hoc tests to find the source of differentiation, and Pearson correlation analysis to determine the relationships between variables. Simple linear regression analysis was used to calculate the predictability. The significance level was accepted as 0.05 in all analyzes. Whether the data meet the requirements of the parametric tests was decided by looking at the Skewness and Kurtosis values and the Levene test results. When the Skewness and Kurtosis values of the independent variables were examined in the study, it was decided that the distribution was between $(-1.5)$ and $(+1.5)$ and that it was suitable for a normal distribution, the applicability of the parametric tests.

\section{Findings}

Descriptive statistics were calculated in order to determine the narcissistic behaviors and job satisfaction of physical education teachers participating in the study, and the results are shown in Table 1.

Table 1. Findings regarding kurtosis-skewness, mean, standard deviation and cronbach alpha values of the scores obtained from the measurement tools

\begin{tabular}{llllllcll}
\hline & N & Min. & Max. & Ort. & Ss & Skewness & Kurtosis $\alpha$ & \\
\hline Narcissism & 195 & 20 & 55 & 37.32 & 7.95 & .033 & -.325 & .839 \\
Job Satisfaction & 195 & 13 & 25 & 20.63 & 3.02 & -.505 & -.319 & .789 \\
\hline
\end{tabular}

When Table 1 is examined, it is seen that the scores of the participants from the Narcissistic Personality Inventory-13 Scale vary between 20 and 55; it was determined that the average was calculated as $37.32( \pm 7.95)$. The scores obtained from the second measurement tool, the Job Satisfaction Scale, also differ between 13 and 25; It was determined that the average was calculated as $20.63( \pm 3.02)$. When the skewness-kurtosis coefficients calculated for the normality assumption of the variables are examined, it is determined that the coefficients take values between -1 and +1 (narcissism: skewness $=.033$; kurtosis $=-.325$; job satisfaction: skewness $=-.505$; kurtosis $=-.319$ ), and it was determined that the variables did not deviate excessively from normal.

The Pearson correlation coefficient was calculated to determine the relationships between the narcissistic behaviors of the physical education teachers participating in the study and their job satisfaction. Results are shown in Table 2.

Table 2. indings based on the relationship between physical education teachers' narcissistic behaviors (authority, grandiose exhibitionism, exploitativeness) and job satisfaction levels

\begin{tabular}{|c|c|c|c|c|c|c|}
\hline $\mathrm{N}=195$ & & 1 & 2 & 3 & 4 & 5 \\
\hline \multirow[t]{2}{*}{ Job Satisfaction } & $\mathrm{r}$ & 1.000 & & & & \\
\hline & $\mathrm{p}$ & & & & & \\
\hline \multirow[t]{2}{*}{ Narcissism } & $\mathrm{r}$ & .138 & 1.000 & & & \\
\hline & $\mathrm{p}$ & .055 & & & & \\
\hline \multirow[t]{2}{*}{ Authority } & $\mathrm{r}$ & $.255^{* *}$ & $.821^{* *}$ & 1.000 & & \\
\hline & $\mathrm{p}$ & .000 & .000 & & & \\
\hline \multirow[t]{2}{*}{ Grandiose Exhibitionism } & $\mathrm{r}$ & .050 & $.812^{* *}$ & $.458^{* *}$ & 1.000 & \\
\hline & $\mathrm{p}$ & .491 & .000 & .000 & & \\
\hline \multirow[t]{2}{*}{ Exploitativeness } & $\mathrm{r}$ & .036 & $.819^{* *}$ & $.575^{* *}$ & $.476^{* *}$ & 1.000 \\
\hline & $\mathrm{p}$ & .614 & .000 & .000 & .000 & \\
\hline Average & & 20.62 & 37.32 & 12.00 & 14.22 & 11.10 \\
\hline Standard Deviation & & 3.02 & 7.95 & 3.17 & 3.58 & 2.98 \\
\hline
\end{tabular}

Note. ${ }^{*} \mathrm{p}<0.05 ; * * \mathrm{p}<0.01$. 
Pearson Product Moment Correlation Coefficient Product was used to examine the relationship between narcissistic behaviors of physical education teachers and job satisfaction. In Table 2, it was found that there is no statistically significant relationship between narcissism total score and job satisfaction $(r=0.138, p>0.05)$. It was found that there was a positive and low level $(r=.255 ; \mathrm{p}<0.05)$ statistically significant relationship between authority and job satisfaction, a sub-dimension of narcissism.

Table 3. Simple linear regression analysis results for predicting the job satisfaction of physical education teachers

\begin{tabular}{llllll}
\hline Variable & B & Standard Error & Beta & t & p \\
\hline Constant & 18.674 & 1.033 & & 18.074 & .00 \\
Narcissism & .052 & .027 & 138 & 1.931 & .55 \\
\hline $\mathbf{R}=\mathbf{. 1 3 8} \mathbf{R}^{\mathbf{2}} \mathbf{0 . 1 4} \mathbf{p}=\mathbf{. 5 5}$ & & & & & \\
\hline
\end{tabular}

A simple linear regression analysis was performed to obtain the results regarding the interpretation of job satisfaction, which is the dependent variable of the study, by narcissistic behaviors. As a result of the analysis, it was stated in the established model that job satisfaction of the variable of narcissism was not statistically significant $\left(\mathrm{R}=0.138, \mathrm{R}^{2}=0.14, \mathrm{~F}=3.730, \mathrm{p}>0.05\right.$. In other words, Narcissism $(=.138, \mathrm{p}>0.05)$ was statistically significant. Information on the results of the analysis is presented in Table 3.

Table 4. T-test results of physical education teachers' narcissism scale and job satisfaction scale scores by gender

\begin{tabular}{llllllll}
\hline Scale & Gender & $\mathbf{N}$ & $\overline{\mathbf{X}}$ & $\mathbf{S S}$ & $\mathbf{S d}$ & $\mathbf{t}$ & $\mathbf{p}$ \\
\hline Narcissism & Female & 41 & 37.30 & 7.23 & 193 & -0.27 & .978 \\
& Male & 154 & 37.33 & 7.78 & & & .970 \\
\hline \multirow{2}{*}{ Job Satisfaction } & Female & 41 & 20.61 & 3.04 & 193 & -.038 & \\
& Male & 154 & 20.63 & 3.02 & & & \\
\hline
\end{tabular}

Note. $* \mathrm{p}<0.05 ; * * \mathrm{p}<0.01$.

Physical education teachers' narcissism behaviors $(\mathrm{t}=-0.27, \mathrm{p}>0.05)$ and job satisfaction levels $(\mathrm{t}=-.038, \mathrm{p}>$ $0.05)$ do not differ significantly according to gender. Narcissism behaviors of male physical education teachers $(\overline{\mathrm{X}}=37.33)$ are higher than female physical education teachers $(\overline{\mathrm{X}}=37.30)$. Male physical education teachers' job satisfaction $(\overline{\mathrm{X}}=20.63)$ is higher than female physical education teachers' $(\overline{\mathrm{X}}=20.61)$. When Table 4 is examined, it is seen that the job satisfaction of the participants does not differ in terms of gender $(p>0.05)$.

Table 5. T-test results of physical education teachers' narcissism scale and job satisfaction scale scores according to branch type

\begin{tabular}{llllllll}
\hline Scale & Branch Type & $\mathbf{N}$ & $\overline{\mathbf{X}}$ & $\mathbf{S S}$ & $\mathbf{S d}$ & $\mathbf{t}$ & $\mathbf{p}$ \\
\hline Narcissism & Team Sports & 101 & 36.88 & 8.21 & 193 & -0.804 & .423 \\
& Individual Sports & 94 & 37.80 & 7.68 & & & \\
\multirow{2}{*}{ Job Satisfaction } & Team Sports & 101 & 20.47 & 3.16 & 193 & -.767 & .442 \\
& Individual Sports & 94 & 20.80 & 2.86 & & & \\
\hline
\end{tabular}

Note. $* \overline{\mathrm{p}<0.05 ; * * \mathrm{p}<0.01}$

Physical education teachers' narcissism behaviors $(t=-0.804, p>0.05)$ and job satisfaction levels $(t=-.767, p>$ $0.05)$ do not differ significantly according to the branch type. Narcissistic behaviors of team sportspeople $(\overline{\mathrm{X}}=$ $36.88)$ are lower than those who do individual sports $(\overline{\mathrm{X}}=37.80)$. The job satisfaction of team sportspeople $(\overline{\mathrm{X}}=$ $20.47)$ is lower than those who do individual sports $(\overline{\mathrm{X}}=20.80)$. When Table 5 is examined, it is seen that the job satisfaction of the participants does not differ in terms of branch types $(\mathrm{p}>0.05)$. 
Table 6. T-test results of physical education teachers' narcissism scale and job satisfaction scale scores according to educational status

\begin{tabular}{llllllll}
\hline Scale & Educational Status & $\mathbf{N}$ & $\overline{\mathbf{X}}$ & SS & Sd & $\mathbf{t}$ & $\mathbf{p}$ \\
\hline Narcissism & Undergraduate & 150 & 36.65 & 7.91 & 193 & -2.168 & $.031^{*}$ \\
& Postgraduate & 45 & 39.56 & 7.76 & & & \\
\multirow{2}{*}{ Job Satisfaction } & Undergraduate & 150 & 20.63 & 3.01 & 193 & .009 & .993 \\
& Postgraduate & 45 & 20.62 & 3.11 & & & \\
\hline
\end{tabular}

Note. ${ }^{*} \mathrm{p}<0.05 ; * * \mathrm{p}<0.01$

A statistically significant difference was found between the narcissism behaviors of postgraduate physical education teachers and the physical education teachers $(t=-2.168, \mathrm{p}<.05)$. Job satisfaction levels $(\mathrm{t}=.009, \mathrm{p}>$ 0.05 ) do not differ significantly according to education level. Narcissism behaviors of postgraduate physical education teachers $(\overline{\mathrm{X}}=39.56)$ are higher than graduate physical education teachers $(\overline{\mathrm{X}}=36.65)$. Postgraduate physical education teachers have lower job satisfaction $(\overline{\mathrm{X}}=20.62)$ than graduate physical education teachers $(\overline{\mathrm{X}}$ $=20.63)$. When Table 6 is examined, it is seen that the job satisfaction of the participants does not differ in terms of educational status $(\mathrm{p}>0.05)$.

Table 7. ANOVA results of physical education teachers' narcissism and job satisfaction scale scores by age

\begin{tabular}{lllllllll}
\hline Scale & Age & N & $\overline{\mathbf{X}}$ & SS & F & sd & $\mathbf{p}$ & $\begin{array}{l}\text { Significant } \\
\text { Difference }\end{array}$ \\
\hline Narcissism & $23-29$ & 19 & 42.11 & 5.02 & 3.24 & 3 & $.023^{*}$ & 3,4 \\
& $30-39$ & 62 & 37.88 & 7.16 & & & & 1 \\
& $40-46$ & 75 & 36.29 & 6.88 & & & & 1 \\
Job Satisfaction & 47 and over & 39 & 36.08 & 10.99 & & & & -712 \\
& $23-29$ & 19 & 21.11 & 3.36 & .458 & 3 & & \\
& $30-39$ & 62 & 20.80 & 2.83 & & & & \\
& $40-46$ & 75 & 20.33 & 3.04 & & & & \\
\hline
\end{tabular}

Note. ${ }^{* \mathrm{p}<0.05 ; * * \mathrm{p}<0.01}$

Analysis results show that there is a significant difference between the narcissism levels of physical education teachers according to age, $\mathrm{F}=3.24, \mathrm{p}<0.05$. The narcissism levels of the participants vary significantly depending on age. Since the equality of variances was ensured in order to find out which groups the differences between units were among and it was a strong test, according to the results of the Tukey HSD test, those between the ages of 23-29 $(\overline{\mathrm{X}}=42.11)$ had narcissism levels of $40-46(\overline{\mathrm{X}}=36.29)$ and 47 and above. $(\overline{\mathrm{X}}=36.08)$ was determined to be higher than those in the age range. When Table 7 is examined, it is seen that the job satisfaction of the participants does not differ according to age $(\mathrm{p}>0.05)$.

Table 8. ANOVA results of physical education teachers' narcissism and job satisfaction scale scores according to the state of doing sports

\begin{tabular}{lllllllll}
\hline Scale & State of doing sports & N & $\overline{\mathbf{X}}$ & SS & F & sd & p & $\begin{array}{c}\text { Significant } \\
\text { Difference }\end{array}$ \\
\hline Narcissism & 3 hours or less & 19 & 35.00 & 7.86 & 5.89 & 4 & $.000^{* *}$ & $2-4-5$ \\
& 4-5 hours & 62 & 38.69 & 8.05 & & & & 1 \\
& 6-7 hours & 75 & 35.26 & 7.68 & & & & 4 \\
& 8-9 hours & 39 & 42.88 & 7.34 & & & & $1-3$ \\
Job Satisfaction & 10 hours or more & 24 & 40.41 & 5.14 & & & & -357 \\
& 3 hours and less & 19 & 20.27 & 3.33 & 1.103 & 4 & & \\
& 4-5 hours & 62 & 20.73 & 2.53 & & & & \\
& 6-7 hours & 75 & 20.41 & 3.52 & & & & \\
\hline
\end{tabular}

Note. ${ }^{*} \mathrm{p}<0.05 ; * * \mathrm{p}<0.01$. 
Analysis results show that there is a significant difference between the narcissism levels of physical education teachers according to the state of doing sports, $\mathrm{F}=5.89, \mathrm{p}<0.01$. The narcissism levels of the participants vary significantly depending on the state of doing sports. Since the equality of variances was ensured in order to find out between which groups the differences between units and it was a strong test, according to the results of the Tukey HSD test, the narcissism levels of those who did sports for 3 hours or less $(\overline{\mathrm{X}}=35.00)$ were found to be 4-5 hours $(\overline{\mathrm{X}}=38.69), 8-9$ hours $(\overline{\mathrm{X}}=42.88)$ and 10 hours and more $(\overline{\mathrm{X}}=40.41)$ are lower than those who do sports. It was determined that those who do sports for $8-9$ hours $(\bar{X}=42.88)$ have higher narcissism levels than those who do sports for $6-7$ hours $(\overline{\mathrm{X}}=35.26)$. When Table 8 is examined, it is seen that the job satisfaction of the participants does not differ according to the state of taking part in sportive activities $(\mathrm{p}>0.05)$.

\section{Discussion and Result}

This study found that 41 women, $21 \%$, age $\bar{X}=39.09$, actively teaching physical education in the provinces of Osmaniye and Kurıkkale in the 2020-2021 academic year; It was conducted with 195 physical education teachers, with 154 males, $79 \%$, age $\bar{X}=40.45$, with a total average age of 40.16 . Within the scope of the research, the narcissistic behaviors of physical education teachers were determined to be at an average level $(\overline{\mathrm{x}}=$ 37.32). Job satisfaction was determined to be at a high $(\overline{\mathrm{x}}=20.63)$ level. In parallel with the findings of the research, Yurdakul, and Bostancı (2016) found that the organizational narcissism level was moderate in total and in all sub-dimensions in their research with teachers. According to the Pearson Correlation test conducted to determine the relationship between narcissistic behaviors and job satisfaction; It was determined that there is a positive and low level statistically significant relationship between authority sub-dimension and job satisfaction. Timuroğlu and İşcan (2008), in their study with managers, stated that they found a strong and inverse relationship between narcissism and job satisfaction dimensions and that narcissists tend to have job dissatisfaction.

Simple linear regression analysis was performed to obtain results regarding the interpretation of job satisfaction by narcissistic behaviors. It was stated in the established model that the narcissism variable was not a statistically significant interpreter of job satisfaction. It was found that there was no statistically significant contribution. According to the results of some studies measuring the relationship between narcissism and job satisfaction, it has been determined that as the narcissism level of employees increases, their job satisfaction increases (Abbas \& Kant, 2017; Abbas \& Karage, 2015). On the contrary, it is possible to see that research results have been reached that narcissistic employees have a lower level of job satisfaction since inflated self-views of individuals with narcissistic personality traits make them think that there are better job alternatives for them (Mathieu, 2013; Mathieu et al., 2014).

It was determined that the narcissistic behaviors and job satisfaction of physical education teachers did not show a significant change according to their gender, however, the narcissistic behaviors and job satisfaction of male physical education teachers were higher than those of female physical education teachers. Similar to the findings of the study, Tozoğlu (2017) found that although there was no difference in narcissistic behaviors according to the gender variable, the average score obtained by male students on the narcissism scale was higher than that of female students. In parallel with the research findings, Orhan (2014) stated that narcissism did not differ according to gender in his study with students. Similarly, Gezer (2017) stated that in the study they conducted with physical education and sports school students, there was no significant difference between the narcissism levels of the students and their gender in terms of total scores. In the results of Kinık (2007)'s doctoral thesis research, it was stated that there was no significant difference between gender and job satisfaction level, similar to the research findings. The conducted studies support the results of this study.

It was determined that the narcissistic behaviors and job satisfaction of physical education teachers did not show a significant change according to the branch type, however, the narcissistic behaviors and job satisfaction of physical education teachers who do individual sports were found to be at a higher level than the physical education teachers engaged in team sports. In the study conducted by Tozoğlu (2017), it was observed that there was no significant difference between the averages of the scores of the students who did team sports and individual sports on the narcissism scale. Although there was no significant difference, it was also revealed that the average score of the students doing team sports on the narcissism scale was higher than the students who did individual sports.

It was determined that the narcissistic behaviors of physical education teachers showed a significant change according to their educational status $(\mathrm{p}<0.05)$. It was determined that the narcissistic behaviors of physical education teachers who received postgraduate education were at a higher level than physical education teachers who had undergraduate degrees. It has been determined that the narcissistic behaviors of physical education 
teachers who are graduates of postgraduate education are at a higher level than physical education teachers who have undergraduate degrees. Similar to the research findings, Cihangiroğlu et al. (2015) stated that the total narcissism score was highest in the final students and then in the 5th-grade students. It can be said that many factors may be effective in the clarification of the narcissistic personality traits of students who have come to the end of a long and difficult education process. Among these, it can be said that he thinks that he is one of the rare people who can achieve the difficult and that he believes that he has the right to expect respect and reward from other people after this stage. In addition, it can be thought that it is effective for him to think that he has the necessary equipment and that he needs no one's mind or friendship, but that they can happen if he wants, and that everyone needs him from now on. It has been determined that job satisfaction levels do not differ significantly according to education level. It can be stated that education level does not have a significant effect on job satisfaction. As a matter of fact, in the study conducted by Yelboğa (2007) with individuals working in a financial institution, it was concluded that education status does not have an effect on job satisfaction.

A significant difference was found between groups in narcissistic behaviors according to the age variable $(\mathrm{p}<$ 0.05). It was determined that this difference was between the 23-29 age group, 40-46, and 47 and over age groups, and when the average values were examined, it was found that the difference was in favor of the 23-29 age group. It was determined that there was no significant difference between the groups in job satisfaction according to the age variable. However, it was determined that the averages of the 23-29 age group are higher than the other age groups. Akınc1 (2015) obtained findings similar to our findings in terms of age groups in his study with university students. He concluded that adolescents in their early 20 s show a higher level of narcissistic tendencies than adolescents older than them. Foster et al. (2003) also stated in their study that older participants show a lower level of narcissistic tendencies. The relationship between age and narcissism also appears to decrease narcissistic tendency with advancing age. He stated that there is a decrease in the characteristics of narcissistic tendency as he gets older.

A significant difference was found between the groups in narcissistic behaviors according to the variable of status of taking part in sportive activities $(p<0.01)$. The difference between those who do sports for 3 hours or less and those who do sports for 4-5 hours, $8-9$ hours, 10 hours or more; was determined that it was between those who did sports for 6-7 hours and those who did sports for 8-9 hours, and when the average values were examined, it was found that the difference was against the group that did sports for 3 hours or less. Similarly, Elman et al. (2003) in their study on football players, it was determined that the narcissism levels of individuals who play football are higher than those of non-athletes. Athletes' feeling of worth depends on their ability to prove themselves superior to others and to inspire admiration in them. They try to attract the attention of other athletes and spectators by exhibiting high-level movements in their branches. Due to this feature of sports, it is thought that it may be effective in the high narcissism level of students who do sports. It was determined that there was no significant difference between the groups in job satisfaction according to the variable of doing sports. However, it was determined that the average of the group that did sports for 10 hours or more was higher than the other age groups. Results obtained from this research; It was found that there was no significant difference in the level of narcissistic behavior of physical education teachers according to gender and branch type. However, it was found that the levels of narcissistic education differed significantly according to the variables of educational status, age, and status of taking part in sportive activities. It has contributed to the current literature that the levels of narcissistic behavior do not affect the job satisfaction of physical education teachers in their professional life.

\section{Limitations and Future Studies}

As in other researches, apart from methodological limitations, this study also has limitations arising from the process and scope, and suggestions for future research. This research was carried out with the convenience sampling method, which is one of the non-random sampling methods, so more generalizable results can be obtained from the studies to be planned with the probability sampling method. Within the scope of the research, only physical education teachers working in Osmaniye and Kurikkale provinces were reached. In this direction, different results can be obtained from the researches that will be carried out by reaching teachers in different branches or working in different provinces.

\section{References}

Abbas, S. M. S., \& Kant, V. (2017). Gender as moderator of narcissism and job satisfaction: Study on comparative assessment of banking and fmcg sectors in Delhi NCR. International Journal of Research in Business Studies and Management, 4(1), 7-15. https://doi.org/10.22259/ijrbsm.0401002

Abbas, S. M. S., \& Karage, A. I. (2015). Narcissism and job satisfaction: An exploratory study of organizations 
in north eastern Nigeria. Research Journal of Commerce \& Behavioural Science, 5(1), 32-41.

Akıncı, İ. (2015). Narsisizm Türleri ve Psikolojik İyilik Hali Arasindaki Ilişki: Duyguların ve Duygu Düzenleme Güçlüklerinin Rolü. Yayınlanmamış Yüksek Lisans tezi, Ankara: Ortadoğu Teknik Üniversitesi, Sosyal Bilimler Enstitüsü.

Ames, D. R., Rose, P., \& Anderson, C. P. (2006). The NPI-16 as a short measure of narcissism. Journal of Research in Personality, 40, 440-450.https://doi.org/10.1016/j.jrp.2005.03.002

Brayfield, A. H., \& Rothe, H. F. (1951). An index of job satisfaction. Journal of Applied Psychology, 35(5), 307. https://doi.org/10.1037/h0055617

Brown, R. P., Budzek, K., \& Tamborski, M. (2009). On the meaning and measure of narcissism. Personality and Social Psychology Bulletin, 35(7), 951-964.https://doi.org/10.1177/0146167209335461

Brummelman, E., Nevicka, B., \& O’Brien, J. M. (2021). Narcissism and leadership in children. Psychological Science, 32(3), 354-363. https://doi.org/10.1177/0956797620965536

Büyüköztürk, Ş., Çakmak, E. K., Akgün, Ö. E., Karadeniz, Ş., \& Demirel, F. (2009). Bilimsel araştırma yöntemleri (3. Baskı). Ankara: Pegem Akademi.

Cihangiroğlu, N., Abdulkadir, T. E. K. E., Uzuntarla, Y., \& Uğrak, U. (2015). Narsist Kişilik Eğilimleri ile Kurumsal Bağlılık Düzeyleri Arasındaki İlişkinin Analizi. Yönetim Ve Ekonomi Araştırmaları Dergisi, 13(1), 1-18. https://doi.org/10.11611/JMER400

Doğan, U., \& Çolak, T. S. (2020). Narsisistik Kişilik Envanteri-13 (NKE-13)'nin Türkçe Geçerlik ve Güvenirlik Çalışması. OPUS Uluslararası Toplum Araştırmaları Dergisi, 15(26), 4166-4184. https://doi.org/10.26466/opus.635725

Elman, W., \& McKelvie, S. (2003). Narcissism in football players: Stereotype or reality. Athletic Insight, 5(1), $38-46$.

Foster, J. D., \& Campbell, W. K. (2007). Are there such things as "narcissists" in social psychology? A taxometric analysis of the Narcissistic Personality Inventory. Personality and Individual Differences, 43, 1321-1332. https://doi.org/10.1016/j.paid.2007.04.003

Foster, J. D., Campbell, W. K., \& Twenge, J. M. (2003). Individual differences in narcissism: Inflated self-views across the lifespan and around the world. Journal of Research in Personality, 37(6), 469-486. https://doi.org/10.1016/S0092-6566(03)00026-6

Gentile, B., Miller, J. D., Hoffman, B. J., Reidy, D. E., Zichner, A., \& Campbell, W. K. (2013). A test of two brief measures of grandiose narcissism: The narcissistic personality inventory-13 and the narcissistic personality inventory-16. Psychological Assessment, 25(4), 1120-1136. https://doi.org/10.1037/a0033192

Gezer, E. (2017). Beden Eğitimi ve Spor Yüksekokulu Öğrencilerinin Narsistik Eğilimleri. Journal of International Social Research, 10(53). https://doi.org/10.17719/jisr.20175334145

Godkin, L., \& Allcorn, S. (2011). Organizational resistance to destructive narcissistic behavior. Journal of Business Ethics, 104(4), 559-570. https://doi.org/10.1007/s10551-011-0930-x

Grapsas, S., Brummelman, E., Back, M. D., \& Denissen, J. J. (2020). The "why" and "how" of narcissism: A process model of narcissistic status pursuit. Perspectives on Psychological Science, 15(1), 150-172. https://doi.org/10.1177/1745691619873350

Grijalva, E., Harms, P. D., Newman, D. A., Gaddis, B. H., \& Fraley, R. C. (2015). Narcissism and leadership: A metaanalytic review of linear and nonlinear relationships. Personnel Psychology, 68, 1-47. https://doi.org/10.1111/peps.12072

Judge, T. A., Locke, E. A., Durham, C. C., \& Kluger, A. N. (1998). Dispositional Effects on Job and Life satisfaction: The Role of Core Evaluations. Journal of Applied Psychology, 83(1), 17. https://doi.org/10.1037/0021-9010.83.1.17

Keser, A., \& Bilir, K. B. Ö. (2019). İş Tatmini Ölçeğinin Türkçe Güvenilirlik ve Geçerlilik Çalışması. Kırklareli Üniversitesi Sosyal Bilimler Dergisi, 3(3), 229-239.

Kınık S., (2007). Kişilik Özellikleri ile İş Doyumu Arasındaki İlişkinin İncelenmesi. Yüksek Lisans Tezi, Sosyal Bilimler Enstitüsü, Eskişehir.

Lubit, R. (2002). The long-term organizational impact of destructively narcissistic managers. Academy of Management Perspectives, 16(1), 127-138. https://doi.org/10.5465/ame.2002.6640218 
Mahmood, A., Akhtar, M. N., Talat, U., Shuai, C., \& Hyatt, J. C. (2019). Specific HR practices and employee commitment: The mediating role of job satisfaction. Employee Relations: The International Journal, 4l(3). https://doi.org/10.1108/ER-03-2018-0074

Mathieu, C. (2013). Personality and job satisfaction: The role of narcissism. Personality and Individual Differences, 55, 650-654. https://doi.org/10.1016/j.paid.2013.05.012

Mathieu, C., Neumann, C. S., Hare, R. D., \& Babiak, P. (2014). A dark side of leadership: Corporate psychopathy and its influence on employee well-being and job satisfaction. Personality and Individual Differences, 59, 83-88. https://doi.org/10.1016/j.paid.2013.11.010

Orhan, G. (2014). Narsisizm etiyolojisi ve dindarlıkla ilişkisi. Yayımlanmış yüksek lisans tezi, Erciyes Üniversitesi, Kayseri.

Reijntjes, A., Vermande, M., Thomaes, S., Goossens, F., Olthof, T., Aleva, L., \& Van der Meulen, M. (2016). Narcissism, bullying, and social dominance in youth: A longitudinal analysis. Journal of Abnormal Child Psychology, 44, 63-74. https://doi.org/10.1007/s10802-015-9974-1

Timuroğlu, K., \& İşcan, Ö. F. (2008). İşyerinde narsisizm ve iş tatmini ilişkisi. Atatürk Üniversitesi İktisadi ve Ídari Bilimler Dergisi, 22(2), 239-264.

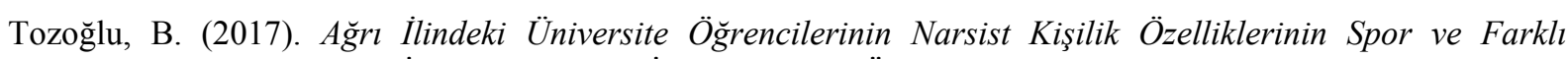
Değişkenler Açısından İncelenmesi. Ağrı İbrahim Çeçen Üniversitesi, Sosyal Bilimler Enstitüsü, Ağrı.

Yelboğa, A. (2007). Bireysel demografik değiş̧kenlerin iş doyumu ile ilişkisinin finans sektöründe incelenmesi. Çağ Üniversitesi Sosyal Bilimler Dergisi, 4(2), 1-18.

Yıldırım, B. I. (2014). Çalışanların Beş Faktör Kişilik Özellikleri İle İş Tatminleri Arasındaki İlişski: Alanya'daki Beş Yıldızlı Oteller Üzerine Bir Uygulama. Akdeniz Üniversitesi Sosyal Bilimler Enstitüs, Antalya.

Yurdakul, A., \& Bostancı, A. B. (2016). Öğretmenlerin Okulların Örgütsel Narsizm Düzeylerine Yönelik Görüşleri İle Öz Yeterlilik Algıları Arasındaki İlişki. Kırıkkale Üniversitesi Sosyal Bilimler Dergisi, 6(1), $109-126$.

\section{Copyrights}

Copyright for this article is retained by the author, with first publication rights granted to the journal.

This is an open-access article distributed under the terms and conditions of the Creative Commons Attribution license (http://creativecommons.org/licenses/by/4.0/). 